\title{
Establishment of the predator Laricobius nigrinus, introduced as a biological control agent for hemlock woolly adelgid in Virginia, USA
}

\author{
Carrie S. Jubb $(\mathbb{D} \cdot$ Thomas J. McAvoy $(\mathbb{D} \cdot$ Kari E. Stanley $(\mathbb{D} \cdot$ Ariel R. Heminger $(\mathbb{D} \cdot$ \\ Scott M. Salom (1)
}

Received: 14 July 2020/ Accepted: 10 December 2020

(C) International Organization for Biological Control (IOBC) 2021

\begin{abstract}
Laricobius nigrinus Fender (Coleoptera: Derodontidae), a predatory beetle native to western North America, has been released since 2003 for management of hemlock woolly adelgid (HWA), Adelges tsugae Annand (Hemiptera: Adelgidae), a non-native pest killing hemlocks in eastern North America. Over 420,000 L. nigrinus have been released in the eastern USA from field and lab-reared sources, 14,000 of which were deployed in the Commonwealth of Virginia, USA. In order to determine the establishment rates of $L$. nigrinus in Virginia, surveys were conducted in 2017 and 2018 at all release sites within this state. During the study, stand-level HWA densities were estimated, and hemlock tree health and predatorprey ratios were quantified. The identification of Laricobius spp. recoveries were made using microsatellite analysis. During the period of the study, L. nigrinus were found to have established at $82 \%$ of Virginia release sites and were the primary species recovered (80\%). Both Laricobius rubidus (18\%) and hybrids $(2 \%)$ were also recovered. Stand-level HWA densities varied greatly over sites and years but
\end{abstract}

Handling Editor: Marta Montserrat.

C. S. Jubb $(\varangle) \cdot$ T. J. McAvoy · K. E. Stanley •

A. R. Heminger - S. M. Salom

Department of Entomology, Virginia Tech, Price Hall,

Room 216A, 170 Drillfield Drive, Blacksburg,

VA 24061, USA

e-mail: cjubb@vt.edu showed a general decline in year two of the study. Establishment at such a high percentage of release sites suggests that the climate in Virginia is suitable for the predator and the insect is adaptable to the wide variety of site conditions where hemlocks typically grow.

Keywords Laricobius nigrinus · Derodontidae . Coleoptera $\cdot$ Adelges tsugae $\cdot$ Hemiptera $\cdot$ Adelgidae

\section{Introduction}

Post-release assessment of natural enemy establishment is a critical component of classical biological control program evaluations. The ability of agents to colonize an introduced region can be a predictor for future success against the pest and can help guide management decisions (van Driesche and Bellows 1996). Laricobius nigrinus Fender (Coleoptera: Derodontidae) is a predatory beetle of hemlock woolly adelgid (HWA), Adelges tsugae Annand (Hemiptera: Adelgidae), a devastating pest causing widespread dieback and mortality of two native hemlock species in eastern forests: Tsuga canadensis (L.) Carriere (eastern hemlock), and Tsuga caroliniana Engelmann (Carolina hemlock) (Havill and Foottit 2007). Laricobius nigrinus has been released in the eastern USA since 2003 as a part of a large-scale biological control 
program implemented for the management of HWA. Although HWA is native to Asia and western North America, it was inadvertently introduced into the eastern USA from Japan (Havill et al. 2006). It has two anholocyclic generations per year (sistens and progrediens) (Havill and Foottit 2007; McClure 1989). Laricobius nigrinus is univoltine (Zilahi-Balogh et al. 2003). Both species are uniquely winter-active. During extensive testing to evaluate the suitability of L. nigrinus as a biological control agent, it was found to be phenologically synchronous with the sistens generation of HWA. This generation produces the eggs of the progrediens generation, which are the primary host of L. nigrinus larvae. Laricobius nigrinus is also highly specific to HWA and during evaluations, only completed development on this species (ZilahiBalogh et al. 2002).

To date, over 420,000 L. nigrinus beetles have been released from field and lab-reared sources throughout the range of HWA infested eastern hemlock (Virginia Tech 2019). In Mausel et al. (2010) establishment of $L$. nigrinus was documented across a wide geographic range of 22 early release sites from Massachusetts to Georgia, suggesting that $L$. nigrinus was adaptable to areas outside of its native environment. Dispersal from original release sites has also been documented (Davis et al. 2012), and movement of this species out of forested release areas and into urban environments further highlights its potential for adaptation (Foley et al. 2019). Investigations evaluating the impact of this predator on the overwintering generation of HWA appear promising (Jubb et al. 2020). However, additional predators are likely necessary for effective management of this species, as the progrediens generation may rebound at some locations after predation of the preceding sistens generation by $L$. nigrinus (Crandall et al. 2020). During previous studies, a native species, Laricobius rubidus Leconte, was also collected from HWA-infested hemlock during sampling (Davis et al. 2012; Mausel et al. 2008, 2010). The primary host for this species is pine bark adelgid (PBA), Pineus strobi Hartig (Hemiptera: Adelgidae) on white pine, Pinus stobus L. (Clark and Brown 1960; Wantuch et al. 2019). However, it can feed and complete development on HWA (ZilahiBalogh et al. 2005). Laricobius nigrinus and $L$. rubidus are closely related sister species that are capable of mating and producing hybrid progeny (Fischer et al. 2015; Havill et al. 2012). Observations by Fischer et al. (2015) showed both species preferred to remain on their primary hosts, while hybrids appeared more frequently on HWA.

As Laricobius spp. release efforts continue throughout the eastern USA, it is critical to engage in post-release monitoring efforts. State-wide evaluation of Laricobius spp. releases can provide an assessment of the effectiveness of biological control efforts and help guide future management efforts. Since the initial releases in 2003, roughly $14,000 \mathrm{~L}$. nigrinus adults have been deployed at 26 locations in the Commonwealth of Virginia in the eastern USA (Virginia Tech 2019). Most releases were made within the Valley and Ridge and Blue Ridge physiographic provinces of Virginia with a small number of releases occurring in the Piedmont and Coastal Plain regions. Prior efforts to evaluate establishment in Virginia have been limited in scope (Heminger 2017; Mausel et al. 2010). In the study reported here, we sampled for $L$. nigrinus at all existing Virginia release sites to understand this beetle's ability to survive under a variety of abiotic conditions state-wide. During those efforts we also classified stand-level HWA densities, hemlock tree health, Laricobius spp. species composition, and predator-prey ratios at each site. The results from this study will help guide future releases of L. nigrinus in Virginia and offer insight to its ability to establish as well as impact HWA populations and hemlock tree health.

\section{Materials and methods}

Field sites

The HWA Predator Release and Monitoring Database (Virginia Tech 2019) was queried in the spring of 2017 to identify all known L. nigrinus release sites in the Commonwealth of Virginia, USA. A total of 26 sites were noted; however, five of those occurred within a one-kilometer radius in the Mountain Lake area and were therefore treated as one site during these investigations (Table 1). All beetle releases made in Virginia were of the coastal strain biotype, which was different from a more cold tolerant interior strain found in Idaho, Montana, and interior British Columbia (Davis et al. 2011; Havill et al. 2012; Mausel et al. 2011). Release sites were situated within four distinct USDA Plant Hardiness Zones: 6a (-23.3 to 
Table 1 Virginia L. nigrinus release site names (listed alphabetically), latitude and longitude, USDA Plant Hardiness Zone of site location, original release dates, and number of predators released

\begin{tabular}{|c|c|c|c|c|c|}
\hline Site name & $\begin{array}{l}\text { Latitude } \\
\text { (decimal degrees) }\end{array}$ & $\begin{array}{l}\text { Longitude } \\
\text { (decimal degrees) }\end{array}$ & Plant hardiness Zone ${ }^{a}$ & L. nigrinus release date & No. released \\
\hline Bear Creek & 36.911486 & -84.401136 & $6 b$ & 2013 & 225 \\
\hline Big Cherry \#1 & 36.827663 & -82.702242 & $6 \mathrm{~b}$ & 2008 & 500 \\
\hline Big Cherry \#2 & 36.832379 & -82.702242 & $6 b$ & 2008 & 500 \\
\hline Burns Creek & 36.924661 & -82.536936 & $6 b$ & 2008 & 300 \\
\hline Channels S.F & 36.828643 & -81.962809 & $6 b$ & 2010 & 1000 \\
\hline $\begin{array}{l}\text { Cherokee } \\
\text { Flats }\end{array}$ & 37.414479 & -80.583234 & $6 b$ & 2014 & 400 \\
\hline Devil's Fork & 36.820031 & -82.630216 & $6 b$ & 2008 & 300 \\
\hline Dickey Creek & 36.736894 & -81.432461 & $6 \mathrm{~b}$ & 2005 & 75 \\
\hline Gullion Fork & 36.995914 & -81.27317 & $6 b$ & 2013 & 225 \\
\hline Highland & 36.692104 & -81.517071 & $6 b$ & 2004 & 1200 \\
\hline Hurricane & 36.721789 & -81.487527 & $6 b$ & 2003 & 300 \\
\hline James River & 37.640505 & -78.79973 & $7 \mathrm{a}$ & 2005 & 300 \\
\hline $\begin{array}{l}\text { Kentland } \\
\text { Farm }\end{array}$ & 37.208931 & -80.589822 & $6 b$ & 2003 & 258 \\
\hline Lick Creek & 37.01072 & -81.427409 & $6 a$ & 2004 & 150 \\
\hline McCoy & 37.214902 & -80.6015 & $6 b$ & $2013 / 2014$ & $150 / 267$ \\
\hline $\begin{array}{l}\text { Mountain } \\
\text { Lake }\end{array}$ & 37.368654 & -80.536671 & $6 a$ & $2009 / 2010$ & $42 / 1800$ \\
\hline Nature Camp & 37.875946 & -79.214285 & $6 \mathrm{~b}$ & 2012 & 430 \\
\hline North Fork & 37.443668 & -80.515333 & $6 b$ & 2003 & 600 \\
\hline Pinnacle & 36.961556 & -82.053298 & $6 b$ & 2006 & 310 \\
\hline Poverty Creek & 37.252649 & -80.533711 & $6 \mathrm{~b}$ & $2009 / 2010 / 2014$ & $150 / 1000 / 539$ \\
\hline Rose Hill & 36.682086 & -83.364423 & $6 b$ & 2014 & 275 \\
\hline $\begin{array}{l}\text { Sandy Point } \\
\text { S.F }\end{array}$ & 37.682968 & -76.944674 & $7 \mathrm{~b}$ & 2010 & 2040 \\
\hline
\end{tabular}

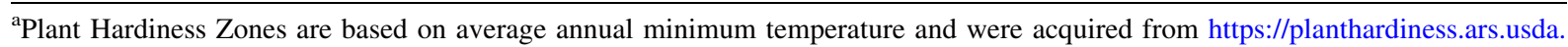
gov. $6 \mathrm{a}\left(-23.3\right.$ to $\left.-20.5{ }^{\circ} \mathrm{C}\right), 6 \mathrm{~b}\left(-20.6\right.$ to $\left.-17.8{ }^{\circ} \mathrm{C}\right), 7 \mathrm{a}\left(-17.8\right.$ to $\left.-15.0{ }^{\circ} \mathrm{C}\right)$ and $7 \mathrm{~b}\left(-15.0\right.$ to $\left.-12.2{ }^{\circ} \mathrm{C}\right)$

$\left.-20.5{ }^{\circ} \mathrm{C}\right), 6 \mathrm{~b}\left(-20.6\right.$ to $\left.-17.8{ }^{\circ} \mathrm{C}\right), 7 \mathrm{a}(-17.8$ to $\left.-15.0{ }^{\circ} \mathrm{C}\right)$ and $7 \mathrm{~b}\left(-15.0\right.$ to $\left.-12.2{ }^{\circ} \mathrm{C}\right)$, with the majority being within 6b (USDA 2012). Sites were visited from March to April in 2017 and 2018 for sampling and coincided with the period of peak HWA egg abundance, L. nigrinus oviposition, and just prior to L. nigrinus larval presence. The exact timing of each site visit varied depending on USDA Plant Hardiness Zone and local temperatures leading up to the sampling period. Colder temperatures delayed HWA and L. nigrinus ovipositional periods. For all locations, visits were planned so that sampling occurred on days where precipitation was not forecast, and temperatures were not below $0{ }^{\circ} \mathrm{C}$, as L. nigrinus would likely not be active (Mausel et al. 2010; Zilahi-Balogh et al. 2003).

HWA density assessment

Approximately 20-30 branches were randomly sampled from the lower canopy ( $0-2 \mathrm{~m}$ above ground) at each site. Current years' growth on a $30 \mathrm{~cm}$ distal portion of each chosen branch was evaluated. The number of HWA $\mathrm{cm}^{-1}$ was approximated for each branch, and an overall mean density was then estimated to achieve a stand-level density assessment. HWA densities were categorized based on the following parameters: 
1. No HWA = HWA not present.

2. Low HWA = An average of fewer than 1 HWA per $30 \mathrm{~cm}$ of current years' growth.

3. Moderate $\mathrm{HWA}=\mathrm{An}$ average between 1-10 HWA per $30 \mathrm{~cm}$ current years' growth.

4. High HWA = An average greater than 10 HWA per $30 \mathrm{~cm}$ current years' growth.

Stand-level HWA density was not estimated at Big Cherry \#2, or Sandy Point State Forest (S.F.) in 2017.

\section{Tree health assessment}

At each site, hemlock tree health was assessed using USDA Forest Service Forest Inventory and Analysis (FIA) crown condition parameters (crown density, transparency, dieback, and live crown ratio) (USDA Forest Service 2011). A percentage value in 5\% increments was assigned for each parameter, and, collectively, these values served as a broad indicator of overall tree health. Ten trees were selected at each site per year, and assessments were performed. A mean percentage for each parameter was then calculated for each site. Evaluations were conducted by the same researcher in both years of the study so as to minimize subjective bias. Tree health was not evaluated at Big Cherry \#2 in 2017, or in either year at Sandy Point S.F.

\section{Laricobius spp. adult sampling (beat sheet method)}

Adult $L$. nigrinus densities were quantified using beat sheet sampling techniques described in Jubb (2019) and Mausel et al. (2010). Sampling was performed for approximately 20-30 min on HWA infested branches in the lower canopy ( $0-2 \mathrm{~m}$ above ground) of hemlock trees throughout the site. Beat sheets were placed under selected HWA infested branches and the upper portion of the branch was then tapped approximately ten times using a $60 \mathrm{~cm}$ section of PVC pipe to dislodge adult Laricobius spp. present on the branch. All adults found on the sheet were collected using an aspirator, and then transferred to vials containing 95\% ethanol for subsequent genetic analysis to determine species or hybrid designation. The total number of adults collected per site was recorded. Beat sheet sampling was not conducted in either year at Mountain Lake or Sandy Point S.F. due to lack of HWA.
Laricobius spp. larval sampling (branch clip method)

Laricobius nigrinus larval densities were quantified using branch clip sampling techniques described in Jubb (2019) and Mausel et al. (2010). Briefly, the distal $30 \mathrm{~cm}$ portion of approximately 20-25 HWA infested branches were selected and cut from the lower canopy of hemlock trees at each site. Branches were transported to the Virginia Tech Insectary and the number of HWA per branch was estimated. Branches were then placed into rearing funnels in conditions known to be appropriate for developing Laricobius spp. larvae (L:D 12:12, $13-15^{\circ} \mathrm{C}$ ) (Lamb et al. 2005; Salom et al. 2012). Larvae were permitted to feed and develop through four instars and were collected as pharate pre-pupae from collection jars attached at the base of funnels. Jars were checked daily for the presence of pre-pupae and, when recovered, were placed into vials filled with $95 \%$ ethanol for genetic analysis. The total number of larvae recovered from each site was quantified and predator-prey ratios were calculated by dividing the total number of larvae recovered per funnel by the total number of HWA present within that funnel for each site. Branches were not collected at Sandy Point State Forest (S.F.) in 2017 or in either year at Mountain Lake, due to the lack of HWA.

Genetic analysis of Laricobius spp. adult and larval recoveries

Microsatellite loci from adult and larval Laricobius spp. recoveries were evaluated to determine species (L. nigrinus or L. rubidus) or hybrid (L. nigrinus $\times L$. rubidus) designation. DNA was extracted from adults and larvae, and six microsatellite loci were amplified using protocols described by Klein et al. (2010). Fragment analysis was performed using a 3730xl 96-Capillary Genetic Analyzer at the DNA Analysis Facility at Science Hill, New Haven, CT, USA. Genotypes were called using Geneious Prime 2019 (Biomatters, Inc, Foster City, CA, USA). Final species and hybrid designations were made using Structure 2.3.2 (Stanford University) and New Hybrids 1.1 (University of California) software programs. At sites where Laricobius spp. recoveries were high, a random subsample of approximately 30 individuals was selected for analysis. 
Statistical analysis

FIA tree health parameters (crown density, transparency, dieback, and live crown) were pooled by year and analyzed to determine if there were differences between values in 2017 and 2018 using a paired t-test at a significance level of $\alpha=0.05$. Tree health parameter response variables were tested for goodness-of-fit to a normal distribution using skewness and kurtosis values (Thode 2002). Dieback variables did not fit a normal distribution and were square-roottransformed to meet the assumptions of the test. Spearman's rank correlation analysis was used to determine the association between Laricobius spp. larval densities and HWA densities in funnels. Additionally, combined adult + larval recoveries were analyzed with stand-level HWA density and the four tree health parameters. All correlation analyses were run at a significance level of $\alpha=0.05$. All statistical analyses were performed using JMP Pro 13.0 (SAS Institute 2018).

\section{Results}

HWA density assessment

HWA densities varied greatly across sites and between years. However, the data indicate a decline in densities at ten sites during the period of the study (Table 2). In 2017 the percentage of sites with no, low, moderate, or high HWA densities was 5, 36, 23, and 27, respectively. In 2018 , the percentage of sites with no, low, moderate, or high HWA densities was 5, 59, 32, and 5, respectively.

\section{Tree health assessment}

Two tree health parameters were significantly different between the two years of the study and indicated that overall hemlock health may have improved in 2018 at L. nigrinus release sites in Virginia. Mean crown density in 2017 was $62 \%$ (range: $45.5-89.0$ ), and in 2018 was 64\% (range: 44.5-91.0), with no significant difference detected between the two years $(t=1.27$, df $=423, p=0.2037)$ (Fig. 1, Table 2). Mean transparency in 2017 was $38 \%$ (range: 9.5-57.5), and in 2018 was $32 \%$ (range: 5.0-56.5), with a significant decrease between the two years $(t=-3.71$, df $=441, p=0.0002)$ (Fig. 1, Table 2). Mean dieback in 2017 was $34 \%$ (range: $8.5-60.0$ ) and in 2018 was $25 \%$ (range: $5.0-49.5$ ), with a significant decrease between the two years $(t=5.97 \mathrm{df}=448$, $p<0.0001$ ) (Fig. 1, Table 2). Mean live crown ratio in 2017 was $63 \%$ (range: $37.5-91.0$ ) and in 2018 was 64\% (range: $31.5-100.0$ ), with no significant difference detected between the two years $(t=0.68$, df $=$ 449, $p=0.4958$ ) (Fig. 1, Table 2).

Laricobius spp. adult sampling (beat sheet method)

A total of 44 Laricobius spp. adults were collected at eight out of $22(36 \%)$ sites in the spring of 2017 (Table 3). Mean ( \pm SE) number of adults collected per site was $2.1 \pm 1.3$ (range: 0-26) with Poverty Creek having the highest number of recoveries. A total of 186 adult Laricobius spp. were collected at 15 out of $22(68 \%)$ sites in 2018 (Table 3). Mean number of adults collected per site was $8.5 \pm 3.7$ (range: $0-80$ ) with the Kentland Farm site having the greatest number of recoveries during the study. No adult recoveries were made at Mountain Lake, Rose Hill, and Sandy Point S.F. throughout the study.

Laricobius spp. larval sampling (branch clip method)

A total of 961 Laricobius spp. larvae were recovered at 15 out of $22(68 \%)$ sites in 2017 (Table 3). Mean number of larvae collected per site was $45.8 \pm 17.2$ (range: 0-343). Mean predator-prey ratio for all sites was $0.03 \pm 0.01$ (range: $0-0.14$ ) (Table 3). Kentland Farm had the greatest number of larval recoveries and the highest predator-prey ratio. A total of 1,503 Laricobius spp. larvae were recovered at 19 out of 22 (86\%) sites in 2018 (Table 3). Mean number of larvae collected per site was $68.9 \pm 14.5$ (range: 0-211) with Highland having the highest number of recoveries. Mean predator-prey ratio for all sites pooled was $0.02 \pm 0.01$ (range: 0-0.10) with Kentland Farm having the greatest predator-prey ratio. No larval recoveries were made at Mountain Lake, Rose Hill, or Sandy Point S.F. during the period of the study.

There was no significant association between the number Laricobius spp. larvae and the number of HWA in funnels. There was a significant positive relationship between combined Laricobius spp. adults + larvae and stand-level HWA density, and a 
C. S. Jubb et al.

Table 2 HWA stand-level density, mean diameter at breast height (DBH), and mean percent \pm SE FIA tree health parameters (crown density, transparency, dieback, and live crown ratio) for Virginia release sites (listed alphabetically) in 2017 and 2018

\begin{tabular}{|c|c|c|c|c|c|c|c|c|c|c|}
\hline \multirow{2}{*}{$\begin{array}{l}\text { Site } \\
\text { Bear Creek }\end{array}$} & \multirow{2}{*}{$\begin{array}{l}\text { Year } \\
2017\end{array}$} & \multirow{2}{*}{$\begin{array}{l}\begin{array}{l}\text { Stand HWA } \\
\text { density }^{\mathrm{a}}\end{array} \\
\text { Moderate }\end{array}$} & $\begin{array}{l}\text { Mean DBH } \\
(\mathrm{cm})\end{array}$ & \multicolumn{2}{|c|}{$\begin{array}{l}\text { Mean \% crown } \\
\text { density }\end{array}$} & \multicolumn{2}{|c|}{$\begin{array}{l}\text { Mean \% } \\
\text { transparency }\end{array}$} & $\begin{array}{l}\text { Mean \% } \\
\text { dieback }\end{array}$ & \multicolumn{2}{|c|}{$\begin{array}{l}\text { Mean } \% \text { live } \\
\text { crown ratio }\end{array}$} \\
\hline & & & $5.9 \pm 1.0$ & 50.5 & \pm 4.5 & 37.0 & \pm 2.7 & $34.5 \pm 2.5$ & 44.0 & \pm 4.2 \\
\hline & 2018 & Low & $11.3 \pm 2.9$ & 62.5 & \pm 3.8 & 33.0 & \pm 5.1 & $24.0 \pm 3.5$ & 41.5 & \pm 5.2 \\
\hline \multirow[t]{2}{*}{ Big Cherry \#1 } & 2017 & Low & $5.4 \pm 1.0$ & 52.5 & \pm 5.1 & 48.0 & \pm 4.1 & $29.5 \pm 5.0$ & 71.0 & \pm 8.5 \\
\hline & 2018 & Moderate & $3.1 \pm 0.4$ & 57.0 & \pm 3.2 & 43.5 & \pm 4.0 & $28.5 \pm 5.7$ & 60.0 & \pm 5.3 \\
\hline \multirow[t]{2}{*}{ Big Cherry \#2 } & 2017 & - & - & - & & - & & - & - & \\
\hline & 2018 & Moderate & $3.9 \pm 0.3$ & 72.5 & \pm 3.7 & 22.5 & \pm 3.2 & $16.0 \pm 5.5$ & 92.0 & \pm 2.2 \\
\hline \multirow[t]{2}{*}{ Burns Creek } & 2017 & Moderate & $13.5 \pm 2.5$ & 45.5 & \pm 6.0 & 57.5 & \pm 3.4 & $39.5 \pm 2.9$ & 37.5 & \pm 4.6 \\
\hline & 2018 & Low & $10.2 \pm 1.7$ & 59.5 & \pm 5.6 & 36.0 & \pm 6.2 & $30.0 \pm 2.9$ & 31.5 & \pm 2.7 \\
\hline \multirow[t]{2}{*}{ Channels S.F } & 2017 & High & $6.4 \pm 3.0$ & 49.0 & \pm 3.4 & 55.5 & \pm 5.5 & $60.0 \pm 6.8$ & 48.0 & \pm 6.2 \\
\hline & 2018 & Low & $11.6 \pm 3.3$ & 52.0 & \pm 3.1 & 41.5 & \pm 5.0 & $35.5 \pm 5.0$ & 56.5 & \pm 3.5 \\
\hline \multirow[t]{2}{*}{ Cherokee Flats } & 2017 & Low & $4.6 \pm 0.8$ & 53.0 & \pm 7.1 & 39.0 & \pm 4.3 & $34.0 \pm 4.7$ & 61.0 & \pm 8.5 \\
\hline & 2018 & Low & $6.2 \pm 0.4$ & 59.0 & \pm 1.9 & 36.5 & \pm 3.2 & $28.0 \pm 3.7$ & 63.0 & \pm 6.7 \\
\hline \multirow[t]{2}{*}{ Devil's Fork } & 2017 & High & $9.7 \pm 2.7$ & 53.5 & \pm 5.8 & 47.5 & \pm 5.8 & $52.0 \pm 5.6$ & 51.5 & \pm 7.0 \\
\hline & 2018 & Low & $5.9 \pm 1.5$ & 44.5 & \pm 7.1 & 56.5 & \pm 5.0 & $49.5 \pm 7.7$ & 55.0 & \pm 5.1 \\
\hline \multirow[t]{2}{*}{ Dickey Creek } & 2017 & High & $6.5 \pm 1.5$ & 52.0 & \pm 4.7 & 46.5 & \pm 4.4 & $48.5 \pm 5.9$ & 52.5 & \pm 7.0 \\
\hline & 2018 & Moderate & $6.8 \pm 1.3$ & 50.5 & \pm 5.4 & 38.0 & \pm 2.2 & $36.5 \pm 5.9$ & 58.0 & \pm 4.6 \\
\hline \multirow[t]{2}{*}{ Gullion Fork } & 2017 & High & $8.3 \pm 2.8$ & 46.0 & \pm 4.9 & 41.5 & \pm 4.7 & $28.0 \pm 4.4$ & 50.0 & \pm 5.5 \\
\hline & 2018 & Low & $11.1 \pm 2.0$ & 52.0 & \pm 3.0 & 31.0 & \pm 1.6 & $25.5 \pm 4.6$ & 44.0 & \pm 4.8 \\
\hline \multirow[t]{2}{*}{ Highland } & 2017 & Low & $12.0 \pm 3.3$ & 85.5 & \pm 2.9 & 19.0 & \pm 2.8 & $12.0 \pm 2.7$ & 81.0 & \pm 4.3 \\
\hline & 2018 & Moderate & $8.0 \pm 1.7$ & 85.0 & \pm 2.6 & 14.0 & \pm 2.8 & $8.0 \pm 2.2$ & 63.5 & \pm 8.6 \\
\hline \multirow[t]{2}{*}{ Hurricane } & 2017 & Low & $8.0 \pm 1.2$ & 55.5 & \pm 4.5 & 42.5 & \pm 3.1 & $39.0 \pm 2.4$ & 58.5 & \pm 4.5 \\
\hline & 2018 & $\mathrm{~L}$ & $6.6 \pm 0.9$ & 65.0 & \pm 3.6 & 31.0 & \pm 2.6 & $34.0 \pm 6.5$ & 73.5 & \pm 5.4 \\
\hline \multirow[t]{2}{*}{ James River S.P } & 2017 & High & $4.3 \pm 0.6$ & 69.0 & \pm 4.2 & 36.5 & \pm 4.9 & $36.0 \pm 4.3$ & 70.0 & \pm 3.8 \\
\hline & 2018 & Moderate & $6.9 \pm 1.6$ & 63.5 & \pm 3.1 & 28.5 & \pm 1.8 & $38.5 \pm 6.7$ & 71.5 & \pm 2.2 \\
\hline \multirow[t]{2}{*}{ Kentland Farm } & 2017 & Low & $5.2 \pm 0.6$ & 89.0 & \pm 4.0 & 9.5 & \pm 3.2 & $8.5 \pm 2.5$ & 91.0 & \pm 3.0 \\
\hline & 2018 & High & $4.4 \pm 0.4$ & 91.0 & \pm 0.8 & 5.0 & \pm 0.0 & $5.0 \pm 0.00$ & 100 & \pm 0.0 \\
\hline \multirow[t]{2}{*}{ Lick Creek } & 2017 & Moderate & $9.2 \pm 1.7$ & 56.0 & \pm 3.5 & 50.5 & \pm 1.8 & $34.5 \pm 3.9$ & 51.0 & \pm 4.0 \\
\hline & 2018 & Low & $12.9 \pm 1.0$ & 62.0 & \pm 2.2 & 42.0 & \pm 3.5 & $30.0 \pm 4.6$ & 59.0 & \pm 5.9 \\
\hline \multirow[t]{2}{*}{ McCoy } & 2017 & Low & $4.0 \pm 0.4$ & 66.0 & \pm 3.8 & 27.5 & \pm 2.8 & $30.0 \pm 4.0$ & 65.0 & \pm 3.7 \\
\hline & 2018 & Low & $2.6 \pm 0.4$ & 58.5 & \pm 2.3 & 38.5 & \pm 3.2 & $28.7 \pm 3.6$ & 62.2 & \pm 3.1 \\
\hline Mountain Lake & 2017 & None & $10.8 \pm 1.0$ & 69.0 & \pm 2.5 & 35.0 & \pm 2.6 & $36.5 \pm 2.4$ & 68.3 & \pm 2.4 \\
\hline & 2018 & None & $10.9 \pm 1.1$ & 68.5 & \pm 1.8 & 29.0 & \pm 2.8 & $12.7 \pm 3.1$ & 72.0 & \pm 2.4 \\
\hline Nature Camp & 2017 & Moderate & $5.3 \pm 1.1$ & 67.0 & \pm 3.5 & 30.0 & \pm 3.3 & $21 \pm 2.45$ & 69.0 & \pm 3.5 \\
\hline & 2018 & Moderate & $7.0 \pm 1.2$ & 69.0 & \pm 2.0 & 26.0 & \pm 1.9 & $12.5 \pm 2.01$ & 72.0 & \pm 2.7 \\
\hline North Fork & 2017 & Low & $9.5 \pm 0.6$ & 67.0 & \pm 3.7 & 32.5 & \pm 3.1 & $32 \pm 1.86$ & 69.0 & \pm 2.4 \\
\hline & 2018 & Low & $7.0 \pm 0.6$ & 60.5 & \pm 2.2 & 43.0 & \pm 4.7 & $37 \pm 4.90$ & 51.0 & \pm 4.2 \\
\hline Pinnacle & 2017 & Low & $7.5 \pm 1.4$ & 75.5 & \pm 1.8 & 23.5 & \pm 3.1 & $20.5 \pm 2.41$ & 71.0 & \pm 2.4 \\
\hline & 2018 & Low & $5.7 \pm 0.7$ & 74.5 & \pm 2.4 & 26.0 & \pm 1.8 & $9.5 \pm 2.52$ & 67.5 & \pm 2.9 \\
\hline Poverty Creek & 2017 & High & $7.4 \pm 1.3$ & 64.0 & \pm 7.0 & 45.0 & \pm 6.6 & $37 \pm 4.23$ & 63.5 & \pm 7.3 \\
\hline & 2018 & Moderate & $3.0 \pm 0.6$ & 59.0 & \pm 4.0 & 33.5 & \pm 3.8 & $32 \pm 3.35$ & 70.0 & \pm 3.3 \\
\hline Rose Hill & 2017 & Moderate & $9.0 \pm 1.9$ & 69.0 & \pm 5.3 & 36.0 & \pm 4.0 & $35 \pm 4.08$ & 74.5 & \pm 5.6 \\
\hline & 2018 & Low & $11.2 \pm 1.7$ & 75.0 & \pm 2.1 & 29.5 & \pm 3.9 & $22 \pm 3.74$ & 58.5 & \pm 5.8 \\
\hline
\end{tabular}


Table 2 continued

\begin{tabular}{llllllll}
\hline Site & Year & $\begin{array}{l}\text { Stand HWA } \\
\text { density }^{\mathrm{a}}\end{array}$ & $\begin{array}{l}\text { Mean DBH } \\
(\mathrm{cm})\end{array}$ & $\begin{array}{l}\text { Mean \% crown } \\
\text { density }\end{array}$ & $\begin{array}{l}\text { Mean \% } \\
\text { transparency }\end{array}$ & $\begin{array}{l}\text { Mean \% } \\
\text { dieback }\end{array}$ & $\begin{array}{l}\text { Mean \% live } \\
\text { crown ratio }\end{array}$ \\
\hline Sandy Point S.F & 2017 & - & - & - & - & - & - \\
& 2018 & Low & - & - & - & - & - \\
\hline
\end{tabular}

${ }^{a}$ Stand-level HWA density categories:

None $=$ HWA not present

Low = average less than 1 HWA per $30 \mathrm{~cm}$ of current years' growth

Moderate = average between 1-10 HWA per $30 \mathrm{~cm}$ current years' growth

High $=$ average greater than 10 HWA per $30 \mathrm{~cm}$ current years' growth

- Data not collected at site

significant negative relationship with crown transparency (Table 4). No significant associations were noted between Laricobius spp. adults + larvae and crown density, dieback, and live crown ratio (Table 4).

Genetic analysis of Laricobius spp. adult and larval recoveries

Laricobius nigrinus was the primary species recovered from Virginia release sites. Laricobius rubidus and hybrids of $L$. nigrinus and $L$. rubidus were also recovered. Recoveries of $L$. nigrinus were made at $82 \%$ of release sites and as such, establishment of this species at those locations can be confirmed (Fig. 2, Table 5). In both years combined, the mean percent $L$. nigrinus recovered at release sites was $80 \%$ followed by $18 \%$ L. rubidus, and $2 \%$ hybrids. In 2017 , the mean percent $L$. nigrinus at release sites was $71 \%$, followed by $27 \%$ L. rubidus, and $2 \%$ hybrids. In 2018 , the mean percent $L$. nigrinus at release sites was $85 \%$ followed by $12 \% L$. rubidus and $3 \%$ hybrids. No recoveries of $L$. nigrinus were made at Nature Camp, Mountain Lake, Rose Hill, or Sandy Point S.F. in either year. Only $L$. rubidus was recovered from Nature Camp during the period of the study. At three sites, Cherokee Flats, Devil's Fork, and North Fork, the adult and larval recovery numbers across both years were $<10(\mathrm{n}=4$, 3, 9, respectively). All other sites had recovery numbers $>10$ across both years (Table 5). Some collected Laricobius individuals were not identifiable due to unsuccessful DNA extraction, or issues with loci amplification as a result of poor sample quality.

\section{Discussion}

Continued evaluation of biological control agents after release is important in order to justify and guide future work with those particular agents (Stiling 1990). Our study was the first comprehensive state-wide evaluation of establishment in the eastern USA the results of which indicate that $L$. nigrinus has colonized successfully a majority of release sites in Virginia. Laricobius nigrinus has been able to persist long-term at many of these locations, and based on original release dates, $\mathrm{F}_{15}$ generation individuals were recovered. They were able to establish within three of the four USDA Plant Hardiness Zones in which they where released, in addition to multiple physiographic regions. These regions are unique in many facets such as elevation, soil characteristics, and overall climate (Virginia Department of Conservation and Recreation 2019), which highlights the adaptability of $L$. nigrinus to different abiotic conditions. This species was also able to persist at sites where stand-level HWA densities were low, an important attribute of successful biological control agents.

Laricobius nigrinus was not recovered at four release sites during the period of this study. Several factors may have negatively affected their ability to establish at these locations. At two of the four sites where establishment was not confirmed (Mountain Lake and Sandy Point S.F.), HWA populations were either not found or were extremely low during the twoyear period of the study. The Mountain Lake sites are situated in Giles, County VA at an elevation of $1100-1200 \mathrm{~m}$. Low winter temperatures frequently experienced at these elevations are a likely cause of 


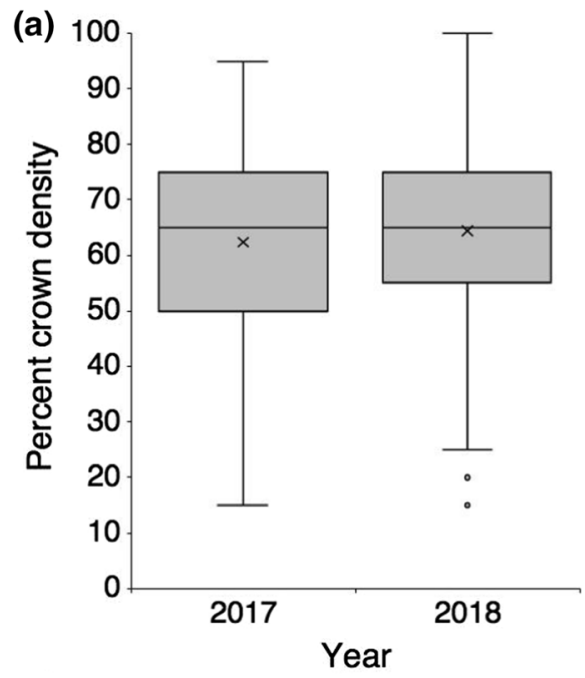

(c)

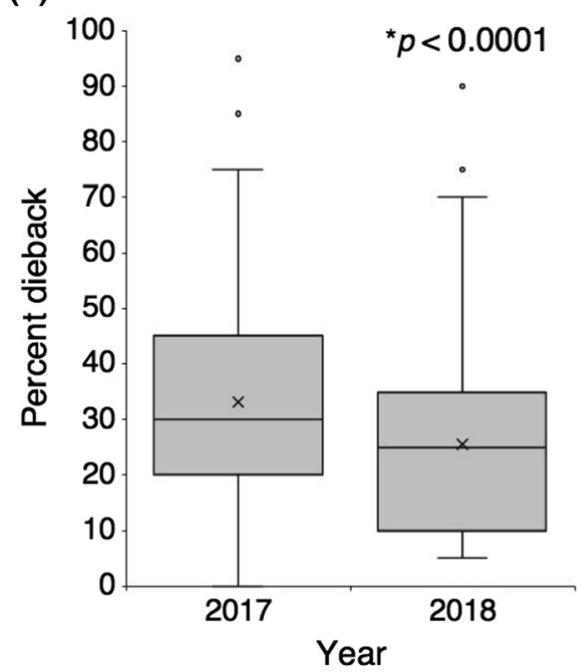

Fig. 1 Box plots depicting 2017 and 2018 mean percent FIA tree health parameters: a crown density, b transparency, c dieback, and $\mathbf{d}$ live crown ratio from $L$. nigrinus release sites in Virginia. Significant differences in parameter values between the two years was tested using a paired t-test. *Significance at

mortality for HWA (McAvoy et al. 2017; Paradis et al. 2008; Tobin et al. 2017; Trotter and Shields 2009) and L. nigrinus populations. Conversely, summer temperatures may also increase HWA mortality (Mech et al. 2018) and could therefore be a potential cause for low HWA populations at Sandy Point S.F., which is located in Zone $7 \mathrm{~b}$. Other factors that may have influenced the ability of $L$. nigrinus to successfully colonize include release size (Mausel et al. 2010) and the timing of the release relative to the life cycle of both L. nigrinus and HWA. If releases are made too

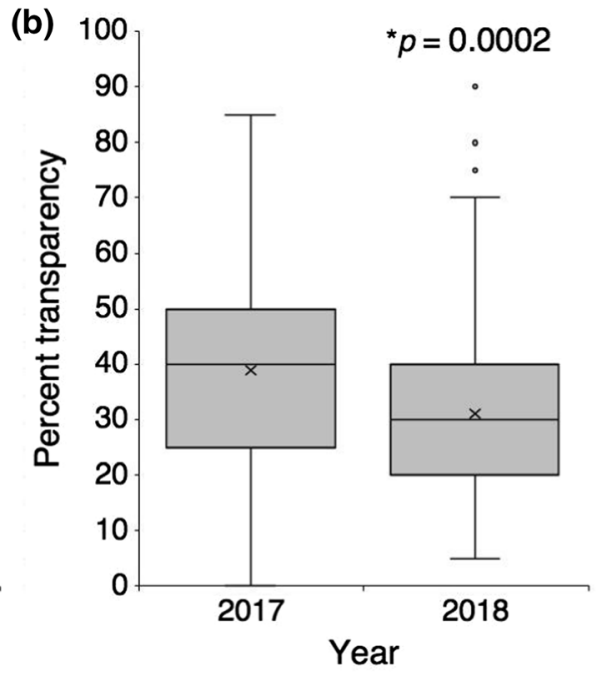

(d)

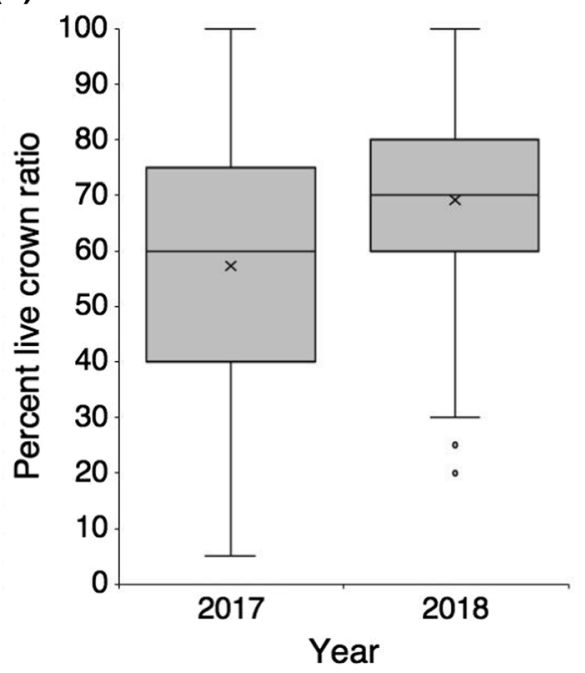

$\alpha=0.05, \mathrm{x}=$ parameter mean, shaded boxes show interquartile range with median indicated by horizontal line, box whiskers extend to minimum and maximum values, circles indicate outliers

late, L. nigrinus may not have sufficient prey on which to feed and develop.

A lack of recoveries at these sites, however, does not necessarily indicate a lack of establishment. Populations of L. nigrinus may have been too low to detect. There were sampling limitations in this study that could have been the cause for low or no recoveries. Both adult and larval sampling was limited to the lower canopy of hemlock trees at most sites due to ease of accessibility specifically with beat sheet sampling. Beat sheet sampling often provides false 
Table 3 The number of Laricobius spp. adults recovered from beat sheet sampling, the number of larval recoveries from branch clip sampling, and the predator-prey ratio (larvae per HWA) in foliage funneled for each Virginia release site (listed alphabetically) in 2017 and 2018

\begin{tabular}{|c|c|c|c|c|c|c|}
\hline \multirow[b]{2}{*}{ Site } & \multicolumn{3}{|l|}{2017} & \multicolumn{3}{|l|}{2018} \\
\hline & Adults & Larvae & $\begin{array}{l}\text { Larvae per } \\
\text { HWA }\end{array}$ & Adults & Larvae & $\begin{array}{l}\text { Larvae per } \\
\text { HWA }\end{array}$ \\
\hline Bear Creek & 2 & 76 & 0.026 & 0 & 24 & 0.025 \\
\hline Big Cherry \#1 & 0 & 5 & 0.002 & 3 & 23 & 0.012 \\
\hline Big Cherry \#2 & 0 & 0 & - & 2 & 24 & 0.007 \\
\hline Burns Creek & 0 & 0 & - & 1 & 27 & 0.019 \\
\hline Channels S.F & 0 & 34 & 0.005 & 4 & 209 & 0.066 \\
\hline Cherokee Flats & 1 & 2 & 0.005 & 0 & 1 & 0.000 \\
\hline Devil's Fork & 0 & 0 & - & 0 & 10 & 0.023 \\
\hline Dickey Creek & 0 & 105 & 0.021 & 11 & 127 & 0.044 \\
\hline Gullion Fork & 0 & 80 & 0.023 & 4 & 52 & 0.017 \\
\hline Highland & 0 & 25 & 0.007 & 15 & 211 & 0.034 \\
\hline Hurricane & 0 & 4 & 0.010 & 6 & 101 & 0.033 \\
\hline James River S.P & 2 & 33 & 0.010 & 12 & 97 & 0.012 \\
\hline Kentland Farm & 8 & 343 & 0.144 & 80 & 188 & 0.096 \\
\hline Lick Creek & 0 & 20 & 0.005 & 5 & 59 & 0.021 \\
\hline McCoy & 3 & 81 & 0.096 & 12 & 96 & 0.058 \\
\hline Mountain Lake & - & - & - & - & - & - \\
\hline Nature Camp & 1 & 21 & 0.003 & 4 & 83 & 0.016 \\
\hline North Fork & 1 & 2 & 0.004 & 0 & 5 & 0.001 \\
\hline Pinnacle & 0 & 0 & 0 & 3 & 58 & 0.021 \\
\hline Poverty Creek & 26 & 130 & 0.074 & 24 & 108 & 0.022 \\
\hline Rose Hill & 0 & 0 & - & 0 & 0 & 0.000 \\
\hline Sandy Point S.F & - & - & - & 0 & 0 & 0.000 \\
\hline
\end{tabular}

-Data not collected at site

Table 4 Spearman's rank correlation results for multiple factors tested at a significance level of $\alpha=0.05$. Highlighted rows indicate significant correlations

\begin{tabular}{|c|c|c|c|}
\hline Factor 1 & Factor 2 & Spearman's $\rho$ & P-Value \\
\hline Laricobius spp. larvae & No. HWA funneled & 0.1556 & 0.3796 \\
\hline $\begin{array}{l}\text { Laricobius spp. } \\
\text { adults + larvae }\end{array}$ & Stand HWA density & 0.3708 & 0.0309 \\
\hline Laricobius spp. adults + larvae & Crown density & 0.2061 & 0.2423 \\
\hline $\begin{array}{l}\text { Laricobius spp. } \\
\text { adults + larvae }\end{array}$ & Transparency & -0.3407 & 0.0486 \\
\hline Laricobius spp. adults + larvae & Dieback & -0.1454 & 0.4121 \\
\hline Laricobius spp. adults + larvae & Live crown ratio & 0.2345 & 0.1819 \\
\hline
\end{tabular}

negatives due to habits of $L$. nigrinus adults (Mausel et al. 2010) and, in this study, recoveries of this life stage were much lower when compared to larval recoveries (Table 4). Additionally, Davis et al. (2012) suggested that $L$. nigrinus adults disperse vertically $(>15 \mathrm{~m})$ within trees following their release, which may have confounded our ability to locate individuals using the two described sampling methods. Further 


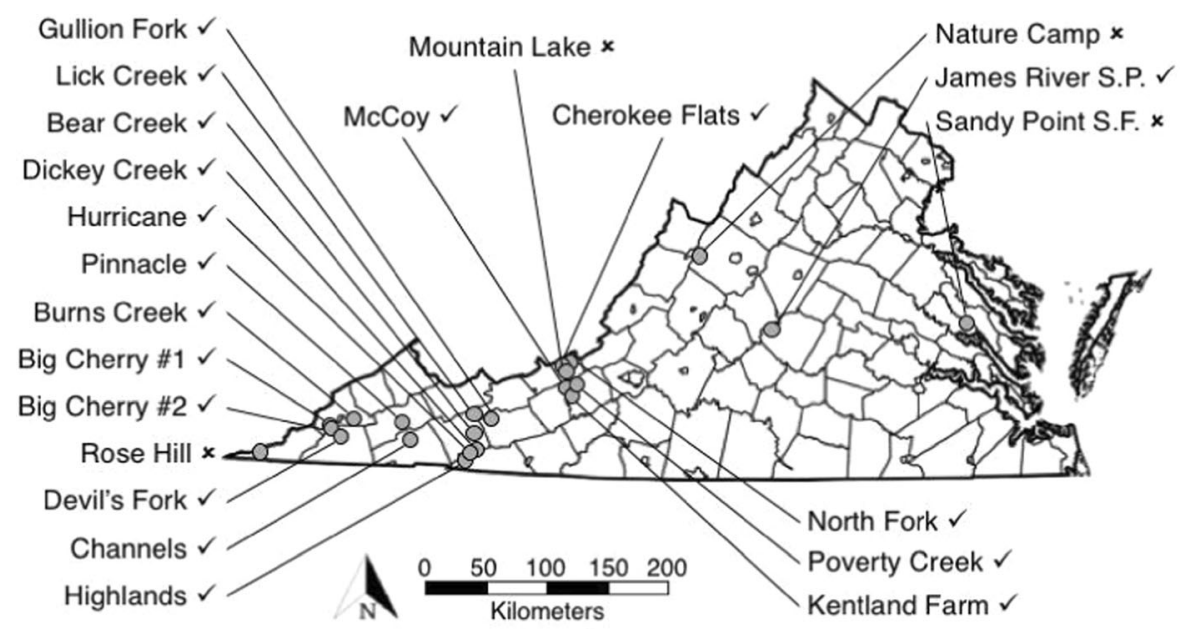

Fig. 2 Combined results of 2017 and 2018 establishment evaluations for L. nigrinus at release sites in the Commonwealth of Virginia, USA. ' $\boldsymbol{V}$ '-Indicates sites where L. nigrinus was recovered; ' $X$ '-Indicates sites where no L. nigrinus recoveries were made

Table 5 The number of samples successfully identified using microsatellite loci analysis, and percent Laricobius recoveries identified as L. nigrinus, L. rubidus, and hybrids for each Virginia release site (listed alphabetically) in 2017 and 2018

\begin{tabular}{|c|c|c|c|c|c|c|c|c|}
\hline \multirow[b]{2}{*}{ Site } & \multicolumn{4}{|c|}{2017} & \multicolumn{4}{|c|}{2018} \\
\hline & $\mathrm{n}$ & \% L. nigrinus & \% L. rubidus & $\%$ Hybrids & $\mathrm{n}$ & $\%$ L. nigrinus & \% L. rubidus & \% Hybrids \\
\hline Bear Creek & 26 & 100 & 0 & 0 & 24 & 100 & 0 & 0 \\
\hline Big Cherry \#1 & 5 & 100 & 0 & 0 & 24 & 4 & 88 & 8 \\
\hline Big Cherry \#2 & $*$ & $*$ & $*$ & $*$ & 25 & 100 & 0 & 0 \\
\hline Burns Creek & $*$ & $*$ & $*$ & $*$ & 28 & 100 & 0 & 0 \\
\hline Channels S.F & 29 & 72 & 28 & 0 & 32 & 88 & 0 & 13 \\
\hline Cherokee Flats & 3 & 0 & 100 & 0 & 1 & 100 & 0 & 0 \\
\hline Devil's Fork & $*$ & $*$ & $*$ & $*$ & 9 & 100 & 0 & 0 \\
\hline Dickey Creek & 30 & 0 & 100 & 0 & 35 & 94 & 3 & 3 \\
\hline Gullion Fork & 28 & 96 & 4 & 0 & 30 & 100 & 0 & 0 \\
\hline Highland & 23 & 100 & 0 & 0 & 37 & 100 & 0 & 0 \\
\hline Hurricane & 7 & 43 & 57 & 0 & 33 & 91 & 3 & 6 \\
\hline James River S.P & 27 & 100 & 0 & 0 & 33 & 100 & 0 & 0 \\
\hline Kentland Farm & 33 & 100 & 0 & 0 & 48 & 100 & 0 & 0 \\
\hline Lick Creek & 18 & 17 & 78 & 6 & 59 & 91 & 2 & 7 \\
\hline McCoy & 58 & 76 & 17 & 7 & 69 & 77 & 19 & 4 \\
\hline Mountain Lake & - & - & - & - & - & - & - & - \\
\hline Nature Camp & 20 & 0 & 100 & 0 & 30 & 0 & 100 & 0 \\
\hline North Fork & 3 & 33 & 67 & 0 & 0 & 0 & 0 & 0 \\
\hline Pinnacle & $*$ & $*$ & $*$ & $*$ & 31 & 100 & 0 & 0 \\
\hline Poverty Creek & 41 & 88 & 10 & 2 & 38 & 87 & 8 & 5 \\
\hline Rose Hill & $*$ & $*$ & $*$ & $*$ & $*$ & $*$ & $*$ & $*$ \\
\hline Sandy Point S.F & - & - & - & - & $*$ & $*$ & $*$ & $*$ \\
\hline
\end{tabular}

-Data not collected at site

* Recoveries not made at site 
investigations of L. nigrinus establishment at sites where they were not initially recovered should therefore include sampling in a variety of canopy positions within trees and should be primarily focused on branch clip sampling for larvae.

Data analyses for two tree health parameters, transparency and dieback, indicated an increase in overall health of hemlocks between the two years of the study. There was also a significant negative association between Laricobius spp. adult and larval recoveries when compared to the tree health parameter, transparency. This suggests that as transparency decreased, Laricobius spp. densities increased in 2018. Although this type of relationship is a positive finding for a biological control program, we cannot confidently make assertions about the relationships of Laricobius spp. densities and tree health using the parameters of this study, as it is difficult to identify trends from a two-year evaluation of the data. In order to have a more consistent and thorough analysis of tree health at Virginia release sites, and an understanding of how Laricobius spp. populations interact with these parameters, sites should be revisited periodically over time to capture important trends.

Genetic analysis of recovered Laricobius spp. suggests that $L$. nigrinus was the species most frequently recovered from Virginia release sites. The percentage of hybrid recoveries in this study (3\%) were lower than in previous studies (11-28\%) (Arsenault et al. 2015; Fischer et al. 2015; Havill et al. 2012; Mayfield et al. 2015; Wiggins et al. 2016). However, our data were more comparable with a recent study where only $2 \%$ of all Laricobius larvae and adults recovered were hybrids (Jubb et al. 2020). While it is possible that hybridization rates have decreased over time at release sites, microsatellite analysis using the six selected loci indicated in Klein et al. (2010) is limited to detecting only earlier generation hybrids. Offspring of prior hybrids could have backcrossed with either species and may have been identified as $L$. nigrinus or L. rubidus by the software programs used in the analysis (Havill et al. 2012). Increasing the number of loci used in microsatellite analysis could improve our ability to detect hybrids and understand how populations of each species are changing spatially and temporally at release sites.

Predator-prey ratios in this study were lower than those indicated in a study conducted in the native range of L. nigrinus (Mausel et al. 2017). The disparity between the findings in the East and West were not explained by the parameters of this study and are therefore not well understood. Many factors such as climate, tree health, lack of tree host resistance and natural enemy complex likely affect predator-prey populations in the East. There was a significant positive relationship between adult + larval densities when compared to HWA stand-level densities, which is consistent with results from previous studies (Mausel et al. 2008; Toland et al. 2018) and suggests a strong relationship between predator and prey. However, further investigations are necessary to have a more thorough understanding of the dynamics involved with L. nigrinus and HWA populations in eastern North America.

Our study provides information that is critical to steering future management of this predator and its prey and also serves as a template for land managers to conduct post-release monitoring of Laricobius spp. populations in their respective regions. We have confirmed L. nigrinus establishment at $82 \%$ of sites in Virginia. Continued monitoring of HWA and $L$. nigrinus populations at non-recovery sites is important to determine establishment status, as populations of both species may have been too low to detect during the period of our study. As predator populations continue to build at some Virginia sites, future work could include collection and redistribution of $L$. nigrinus to other suitable release areas in the eastern USA Future releases must be made at sites with adequate HWA populations to support the release size and must be made during the appropriate time period in order to have a higher probability of establishment. The results of this study further support previous findings that $L$. nigrinus is adaptable to climatic and other environmental conditions outside of its native range (Mausel et al. 2010) and can persist in these environments in spite of low prey populations. These are qualities of potentially successful biological control agents.

Acknowledgements We thank Drs. Thomas Kuhar, Albert Mayfield, and Douglas Pfeiffer for thoughtful review of this project. We are grateful to Drs. Nathan Havill (USDA Forest Service) and Melissa Fischer (Washington State Department of Natural Resources) for assistance with molecular protocols, and to Natalie Morris, Kara Jeffries, Andy Dechaine, Ryan Mays, James Wahls (Virginia Tech) for field and laboratory assistance. We also thank Scott Passwaters (James River State Park), the staff at the Big Stone Gap Water Treatment Plant, Philip Coulling (Nature Camp), and Dennis Gaston, Katlin DeWitt and 
Lori Chamberlin (Virginia Department of Forestry) for site assistance.

Funding This work was funded under USDA Forest Service cooperative agreement 14-CA-11420004-028.

\section{Compliance with ethical standards}

Conflict of interest The authors declare that they have no known conflicts of interest.

\section{References}

Arsenault AL, Havill NP, Mayfield AE, Wallin KF (2015) Behavioral responses of Laricobius spp. and hybrids (Coleoptera: Derodontidae) to hemlock woolly adelgid and adelgid host tree odors in an olfactometer. Environ Entomol 44:1562-1570

Clark RC, Brown NR (1960) Studies of predators of the balsam woolly aphid, Adelges piceae (Ratz.) (Homoptera: Adelgidae), VII. Laricobius rubidus (Lec.) (Coleoptera: Derodontidae), a predator of Pineus strobi (Htg.) (Homoptera: Adelgidae). Can Entomol 92:237-240

Crandall RS, Jubb CS, Mayfield AE, Thompson B, McAvoy TJ, Salom SM, Elkinton JS (2020) Rebound of Adelges tsugae spring generation following predation on overwintering generation ovisacs by the introduced predator Laricobius nigrinus in the eastern United States. Biol Control 145:104264

Davis GA, Havill NP, Adelman ZN, Caccone A, Kok LT, Salom SM (2011) DNA barcodes and molecular diagnostics to distinguish an introduced and native Laricobius (Coleoptera: Derodontidae) species in eastern North America. Biol Control 58:53-59

Davis GA, Salom SM, Brewster CC, Onken BP, Kok LT (2012) Spatiotemporal distribution of the hemlock woolly adelgid predator Laricobius nigrinus after release in eastern hemlock forests. Agric For Entomol 14:408-418

Fischer MJ, Havill NP, Brewster CC, Davis GA, Salom SM, Kok LT (2015) Field assessment of hybridization between Laricobius nigrinus and L. rubidus, predators of adelgidae. Biol Control 82:1-6

Foley JR, McAvoy TJ, Dorman S, Bekelja K, Kring TJ, Salom SM (2019) Establishment and distribution of Laricobius spp. (Coleoptera: Derodontidae), a predator of hemlock woolly adelgid, within the urban environment in two localities in southwest Virginia. J Integr Pest Manag 10(30): $1-4$

Havill NP, Montgomery ME, Yu GY, Shiyake S, Caccone A (2006) Mitochondrial DNA from hemlock woolly adelgid (Hemiptera: Adelgidae) suggests cryptic speciation and pinpoints the source of the introduction to eastern North America. Ann Entomol Soc Am 99:195-203

Havill NP, Foottit RG (2007) Biology and evolution of Adelgidae. Annu Rev Entomol 52:325-349

Havill NP, Davis G, Mausel DL, Klein J, McDonald R, Jones C, Fischer M, Salom S, Caccone A (2012) Hybridization between a native and introduced predator of Adelgidae: an unintended result of classical biological control. Biol Control 63:359-369

Heminger AR (2017) Establishment of Laricobius nigrinus (Coleoptera: Derodontidae) in Virginia and assessment of its impact on hemlock woolly adelgid, Adelges tsugae (Hemiptera: Adelgidae), throughout the eastern U.S. M.S. thesis. Virginia Tech, Blacksburg

Jubb CS (2019) Evaluation of the establishment of predatory beetle, Laricobius nigrinus (Coleoptera: Derodontidae) in Virginia, and assessment of its impact on hemlock woolly adelgid (Hemiptera: Adelgidae) at release sites in the eastern U.S. M.S. thesis. Virginia Tech, Blacksburg

Jubb CS, Heminger AR, Mayfield AE, Elkinton JS, Wiggins GJ, Grant JF, Lombardo JA, McAvoy TJ, Crandall RS, Salom SM (2020) Impact of the introduced predator, Laricobius nigrinus, on ovisacs of the overwintering generation of hemlock woolly adelgid in the eastern United States. Biol Control 143:104180

Klein JL, Caccone A, Havill NP (2010) Polymorphic microsatellite loci for Laricobius nigrinus and L. rubidus (Coleoptera: Derodontidae), predators of the hemlock woolly adelgid. Mol Ecol Resour 10:751-754

Lamb AB, Salom SM, Kok LT (2005) Guidelines for rearing Laricobius nigrinus fender. In: Onken B, Reardon R (eds) Proceedings of the third symposium on hemlock woolly adelgid in the eastern United States, 2005. USDA Forest Service FHTET-2005-01, pp. 309-318

Mausel DL, Salom SM, Kok LT, Fidgen JG (2008) Propagation, synchrony, and impact of introduced and native Laricobius spp. (Coleoptera: Derodontidae) on hemlock woolly adelgid in Virginia. Environ Entomol 37:1498-1507

Mausel DL, Salom SM, Kok LT, Davis GA (2010) Establishment of the hemlock woolly adelgid predator, Laricobius nigrinus (Coleoptera: Derodontidae), in the eastern United States. Environ Entomol 39:440-448

Mausel DL, van Driesche RG, Elkinton JS (2011) Comparative cold tolerance and climate matching of coastal and inland Laricobius nigrinus (Coleoptera: Derodontidae), a biological control agent of hemlock woolly adelgid. Biol Control 58:96-102

Mausel DL, Kok LT, Salom SM (2017) Numerical response and impact of Laricobius nigrinus (Coleoptera: Derodontidae) on Adelges tsugae (Hemiptera: Adelgidae) in their native range. Environ Entomol 46:544-551

Mayfield AE, Reynolds BC, Coots CI, Havill NP, Brownie C, Tait AR, Hanula JL, Joseph SV, Galloway AB (2015) Establishment, hybridization and impact of Laricobius predators on insecticide-treated hemlocks: exploring integrated management of the hemlock woolly adelgid. For Ecol Manage 335:1-10

McAvoy TJ, Régnière J, St-Amant R, Schneeberger NF, Salom SM (2017) Mortality and recovery of hemlock woolly adelgid (Adelges tsugae) in response to winter temperatures and predictions for the future. Forests 8:497

McClure MS (1989) Evidence of a polymorphic life-cycle in the hemlock woolly adelgid, Adelges tsugae (Homoptera: Adelgidae). Ann Entomol Soc Am 82:50-54

Mech AM, Tobin PC, Teskey RO, Rhea JR, Gandhi KJK (2018) Increases in summer temperatures decrease the survival of an invasive forest insect. Biol Invasions 20:365-374 
Paradis A, Elkinton J, Hayhoe K, Buonaccorsi J (2008) Role of winter temperature and climate change on the survival and future range expansion of the hemlock woolly adelgid (Adelges tsugae) in eastern North America. Mitig Adapt Strat Gl 13:541-554

Salom SM, Kok LT, Lamb AB, Jubb CS (2012) Laboratory rearing of Laricobius nigrinus (Coleoptera: Derodontidae): a predator of the hemlock woolly adelgid (Hemiptera: Adelgidae). Psyche 2012:936519

SAS Institute (2018) JMP Pro 13.0. Cary, NC

Stiling P (1990) Calculating the establishment rates of parasitoids in classical biological control. Am Entomol $36: 225-230$

Thode HC (2002) Testing for normality. Marcel Dekker, New York, NY

Tobin PC, Turcotte RM, Blackburn LM, Juracko JA, Simpson BT (2017) The big chill: quantifying the effect of the 2014 north American cold wave on hemlock woolly adelgid populations in the central appalachian mountains. Popul Ecol 59:251-258

Toland A, Brewster C, Mooneyham KL, Salom SM (2018) First report on establishment of Laricobius osakensis (Coleoptera: Derodontidae) a biological control agent for hemlock woolly adelgid Adelges tsugae (Hemiptera: Adelgidae) in the eastern U.S. Forests 9:496

Trotter TR, Shields KS (2009) Variation in winter survival of the invasive hemlock woolly adelgid (Hemiptera: Adelgidae) across the eastern United States. Environ Entomol 38:557-587

USDA (2012) USDA plant hardiness zone map. United States department of agriculture. https://planthardiness.ars.usda. gov/PHZMWeb/. Accessed 2 Oct 2018

USDA forest service (2011) Crowns: measurements and sampling. In: Phase 3 field guide, version 5.1. USDA Forest Service, pp 1-22

van Driesche R, Bellows TS (1996) Biological control. Chapman and Hall, New York

Virginia Department of Conservation and Recreation (2019) Native plants for conservation, restoration, and landscaping. Virginia department of conservation and recreation. https://www.dcr.virginia.gov/natural-heritage/vaphysiographic-provinces. Accessed 12 July 2020

Virginia Tech (2019) HWA predator database. Virginia Tech. http://hiro.ento.vt.edu/pdb/. Accessed 20 Sep 2017
Wantuch HA, Havill NP, Hoebeke ER, Kuhar TP, Salom SM (2019) Predators associated with the pine bark adelgid (Hemiptera: Adelgidae), a native insect in Appalachian forests, United States of America, in its southern range. Can Entomol 151:73-84

Wiggins GJ, Grant JF, Rhea JR, Mayfield AE, Hakeem A, Lambdin PL, Galloway ABL (2016) Emergence, seasonality, and hybridization of Laricobius nigrinus (Coleoptera: Derodontidae), an introduced predator of hemlock woolly adelgid (Hemiptera: Adelgidae), in the Tennessee Appalachians. Environ Entomol 45:1371-1378

Zilahi-Balogh GMG, Kok LT, Salom SM (2002) Host specificity of Laricobius nigrinus fender (Coleoptera: Derodontidae), a potential biological control agent of the hemlock woolly adelgid, Adelges tsugae Annand (Homoptera: Adelgidae). Biol Control 24:192-198

Zilahi-Balogh GMG, Humble LM, Lamb AB, Salom SM, Kok LT (2003) Seasonal abundance and synchrony between Laricobius nigrinus (Coleoptera: Derodontidae) and its prey, the hemlock woolly adelgid (Hemiptera: Adelgidae). Can Entomol 135:103-115

Zilahi-Balogh GMG, Broeckling CD, Kok LT, Salom SM (2005) Comparison between a native and exotic adelgid as hosts for Laricobius rubidus (Coleoptera: Derodontidae). Biocontrol Sci Technol 15:165-171

Carrie S. Jubb assisted with the design of the project, conducted the investigations and data analysis, and wrote the original draft of the manuscript.

Thomas J. McAvoy assisted with the investigations and reviewed and edited the manuscript.

Kari E. Stanley assisted with the investigations and reviewed and edited the manuscript.

Ariel R. Heminger assisted in the design of the project and reviewed and edited the manuscript.

Scott M. Salom conceptualized and designed the project, and reviewed and edited the manuscript. 